\title{
Simple Aromatics Identified with a NFAT-lacZ Transcription Assay for the Detection of Immunosuppressants
}

\author{
Neal S. Burres, Usha Premachandran, Sharon Hoselton, Dolores Cwik, Jill E. Hochlowski, \\ Qingmei Ye, Gabriela N. Sunga, James P. Karwowski, Marianna Jackson, \\ DAVID N. WhitTERn and JAMES B. MCAlpine
}

\begin{abstract}
New Lead Discovery, Pharmaceutical Products Research and Development, Abbott Laboratories,
\end{abstract} Abbott Park., Illinois 60064, U.S.A.

(Received for publication January 17, 1995)

\begin{abstract}
Determination of the mechanism of action of FK506 and cyclosporin A has yielded new molecular targets involved in signal transduction during $\mathrm{T}$ cell activation. A common target of FK506 and cyclosporin A is inhibition of activation of the NFAT transcription factor, for which a specific binding region is present in the promoter of the IL-2 gene. A reporter gene assay has been used to screen for agents that interfere with this early step in $\mathrm{T}$ cell activation. Simple aromatic compounds that block NFAT-dependent transcription and show in vitro immunosuppressive activity were isolated from the broth and mycelia of two Streptomyces sp. fermentations. The compounds were active at concentrations that were not directly cytotoxic.
\end{abstract}

$T$ cell activation is a critical event for initiation and regulation of immune responses and inhibitors of signaling pathways are clinically useful for the treatment of transplant rejection and autoimmunity. Both cyclosporin A and FK506 block the production of IL-2 by disrupting $\mathrm{T}$ cell activation pathways involving $\mathrm{Ca}^{2+}$ mobilization. ${ }^{1)}$ Despite similar biological effects, the two drugs are structurally different and bind uniquely to two distinct cytosolic proteins. ${ }^{2,3)}$ Cyclosporin A binds to cyclophilins and FK 506 binds to FKBPs. Cyclophilins and FKBPs are ubiquitous highly conserved proteins that share no primary or tertiary homology. However, both proteins catalyze peptidylpropyl isomerization and may fold proteins in vivo. Although binding of the drugs to their respective immunophilins results in inhibition of peptidylproline isomerization this activity is not directly related to immunosuppression. ${ }^{4}$ Using constructs in which mRNA production controlled by a specific transcription factor could be measured, it was demonstrated that both FK506 and cyclosporin A inhibited transcription activated by NFAT, a heterodimer that binds to a specific sequence present in the IL-2 promoter region. ${ }^{5)}$ To find the factors mediating inhibition, affinity chromatography was used to search for proteins that bind FK506-FKBP and cyclosporin A-cyclophilin. Calcineurin, a serinethreonine phosphatase, was found to bind to both complexes and was the major target in tissue and cell extracts. ${ }^{6}$ Binding of drug-immunophilin complexes to calcineurin inhibits the phosphatase activity which either directly or indirectly regulates NFAT function by controlling the phosphorylation-dependent nuclear translo- cation of the cytosolic component of NFAT. ${ }^{1)}$ Since production of IL-2 is an important early event in T cell activation, inhibition of NFAT-dependent transcription represents a defined functional screen for potential immunosuppressants.

Using a NFAT-lacZ $\beta$-galactosidase reporter gene construct that has three copies of the NFAT binding region ligated to a minimal IL-2 promoter and the lac $\mathbf{Z}$ gene we have screened extracts of microbial fermentations for immunosuppressants. Agents that block NFAT-dependent transcription may act at any of the known, or as yet undescribed, early $\mathrm{Ca}^{2+}$ dependent signaling pathways in $\mathrm{T}$ cell activation. Following 6 hour exposures to phorbol ester and ionomycin, NFATdependent expression of $\beta$-galactosidase, the product of the lac $\mathbf{Z}$ gene, is easily detected with 4-methylumbelliferyl $\beta$-D-galactoside. Cyclosporin A and FK506 strongly inhibit this response at concentrations that do not result in detectable toxic effects on the cells. In this report we describe the isolation, structure, and biological activity of new substituted aromatics from two different Streptomyces sp. that also inhibit NFAT-dependent transcription.

\section{Materials and Methods}

Microorganisms

Both cultures described in this report were isolated from soil samples obtained in north central Nigeria. Strain AB 2199J-103 (producer of NFAT-68) was isolated from soil collected from a cashew orchard using the method described by HAYAKAWA et al. ${ }^{7)}$ for obtain- 
ing Dactylosporangium. Strain AB 2184C-502 (producer of NFAT-133) was isolated from a corn field soil using a method designed to increase the range of diverse cultures that can be isolated from a soil by plating it on several media differing only by nitrogen source. The control medium was a modified Gause No. 1 agar containing soluble starch (Baker) $0.1 \%, \mathrm{KNO}_{3} 0.1 \%$, yeast extract (Difco) $0.01 \%, \mathrm{~K}_{2} \mathrm{HPO}_{4} 0.05 \%, \mathrm{MgSO}_{4}$ $0.05 \%, \mathrm{NaCl} 0.05 \%, 1.0 \mathrm{ml}$ of a trace element solution per $\operatorname{liter}^{8)}$ and agar $2.0 \%$. The medium was amended with cycloheximide $(50 \mu \mathrm{g} / \mathrm{ml})$, nystatin $(20 \mu \mathrm{g} / \mathrm{ml})$ and nalidixic acid $(30 \mu \mathrm{g} / \mathrm{ml})$. AB $2184 \mathrm{C}-502$ was isolated from an experimental medium which substituted histidine $0.125 \%$ for $\mathrm{KNO}_{3}$ as a sole nitrogen source. Subcultures of each microorganism were deposited at the National Center for Agricultural Utilization Research, United States Department of Agriculture, 1815 North University Street, Peoria, Illinois, 61604 U.S.A. The accession codes of strains AB 2199J-103 and AB 2184C-502 are NRRL B-16948 and NRRL B-16949, respectively.

\section{Taxonomic Studies}

The cultural characteristics of strains AB 2199J-103 and 2184C-502 were examined using the methods and media described by SHIRLING and GoTTLIEB. ${ }^{9)}$ Incubation for cultural characteristics was at $28^{\circ} \mathrm{C}$ for 21 days. Analysis of the whole-cell diaminopimelic acid isomer was done by the method of HASEGAWA, et al. ${ }^{10)}$ Color names were assigned to the mycelial and diffusible pigments on the basis of the Inter-Society Color Council-National Bureau of Standards (ISCC-NBS) Centroid Color Charts. ${ }^{11)}$

\section{Fermentation}

NFAT-68 was produced by submerged fermentation of strain AB 2199J-103 in a medium consisting of glucose monohydrate $2 \%$, molasses $0.5 \%$, Lexein F-152 liquid peptone (Inolex Chemical Co.) $1 \%$, primary yeast $0.5 \%$, $\mathrm{CaCO}_{3} \quad 0.2 \%$ and Amberlite XAD-16 resin (Rohm \& Haas) $5 \%$. Inoculum preparation and operation of the fermentation was as described below for NFAT-133 except that a 42-liter fermentor charged with 30 liters of medium was used. The NFAT-68 fermentor was harvested after 5 days.

NFAT-133 was produced by fermentation in a 22-liter stirred vessel (LH Fermentation) charged with 15 liters of a medium consisting of soluble starch $3 \%$, molasses $2 \%$, spray-dried lard water (Inland Molasses Co.) $1 \%$, brewer's yeast $0.5 \%, \mathrm{CaCO}_{3} 0.2 \%$ and Amberlite XAD-4 resin (Rohm \& Haas) 5\%. The medium was prepared in distilled water and the $\mathrm{pH}$ was adjusted to 7 . Sterilization was at $121^{\circ} \mathrm{C}$ and $1.05 \mathrm{~kg} / \mathrm{cm}^{2}$ for 1 hour. Inoculum for the fermentation was prepared in 2-liter Erlenmeyer flasks containing $600 \mathrm{ml}$ of a medium consisting of glucose monohydrate $1.5 \%$, soy flour $1.5 \%$, yeast extract (Difco) $0.1 \%, \mathrm{NaCl} 0.1 \%$ and $\mathrm{CaCO}_{3} 0.1 \%$ in distilled water. The flasks were seeded at $0.5 \%$ with vegetative mycelium from previous inoculum which had been maintained at $-70^{\circ} \mathrm{C}$. Incubation of the seed flasks was at $28^{\circ} \mathrm{C}$ for 72 hours on a rotary shaker operated at $225 \mathrm{rpm}$ ( $5.08 \mathrm{~cm}$ stroke). The resulting growth was used at $5 \%$ to inoculate the fermentor. During fermentation the temperature was controlled at $28^{\circ} \mathrm{C}$, agitation was $250 \mathrm{rpm}$, the air flow was $0.7 \mathrm{vol} / \mathrm{vol} / \mathrm{minute}$ and the head pressure was maintained at $0.35 \mathrm{~kg} / \mathrm{cm}^{2}$. Foam was controlled with a silicone antifoam, XFO 371 (Ivanhoe Industries), added initially at $0.01 \%$ and then available on demand. The fermentation was harvested on the 5 th day.

\section{Structure Determination}

Fast atom bombardment mass spectra were measured on a Kratos MS-50 mass spectrometer. Ultraviolet spectra were recorded on a Perkin-Elmer Lambda 3B UV-visible spectrophotometer. Infrared spectra were recorded on a Nicolet model 60SX FT-IR. Nuclear magnetic resonance spectra were acquired on a General Electric GN500 spectrometer.

\section{NFAT Assay}

The Fgl-5 Jurkat cell line, obtained from GerALD CrabTREe, Stanford University, has NFAT specific enhancer regions which regulate the activity of the IL-2 promoter on CD-8 and $\beta$-gal reporter genes. Cells were maintained in RPMI-1640 with $10 \%$ fetal bovine serum and $50 \mu \mathrm{g} / \mathrm{ml}$ hygromycin-B (the plasmid used to transfect the Jurkat cells contained a hygromycin resistance marker) in a humidified atmosphere containing $5 \% \quad \mathrm{CO}_{2}$. Cultures $\left(25 \sim 100 \mathrm{ml}, 2 \times 10^{5}\right.$ cells $\left./ \mathrm{ml}\right)$ were established in plastic tissue culture flasks and cells were stimulated the next day by the addition of $2 \mu \mathrm{M}$ ionomycin and $32 \mathrm{nM}$ phorbol myristate acetate (final concentrations). Cultures were established in 96-well microtiter trays $(200 \mu \mathrm{l} / \mathrm{well})$ and incubated for 5 hours. After the incubation, the cells were pelleted by centrifugation and the culture fluids removed by aspiration. $\beta$-Galactosidase reaction medium $(180 \mu \mathrm{l} ; 100 \mathrm{~mm}$ sodium phosphate $\mathrm{pH}$ $7.0,10 \mathrm{~mm} \mathrm{KCl}^{1} \mathrm{~mm} \mathrm{MgSO}, 0.1 \%$ Triton $\mathrm{X}-100$ and $0.5 \mathrm{~mm} 4$-methylumbelliferyl $\beta$-D-galactoside) was added to each well and incubated 1 hour at $37^{\circ} \mathrm{C}$. The reaction was stopped by the addition of $75 \mu \mathrm{l}$ of a stop buffer ( $300 \mathrm{~mm}$ glycine and $15 \mathrm{~mm}$ EDTA pH 11.3) per well. The fluorescence at $460 \mathrm{~nm}$ was measured using $355 \mathrm{~nm}$ excitation with a Millipore Cytofluor 2350.

\section{Calcineurin Phosphatase Activity}

Bovine brain calcineurin and calmodulin (Sigma) were mixed in reaction buffer $(20 \mathrm{~mm}$ Tris-acid $\mathrm{pH} 7.4,0.1 \mathrm{M}$ $\mathrm{NaCl}, 6 \mathrm{~mm} \mathrm{MgCl}_{2}, 1 \mathrm{~mm} \mathrm{CaCl}, 3 \mathrm{~mm} \mathrm{MnCl}_{2}, 0.5 \mathrm{~mm}$ dithiothreitol, 0.19 Triton $\mathrm{X}-100$ and $0.1 \mathrm{mg} / \mathrm{ml}$ bovine serum albumin (Sigma, type V) with calmodulin in a 10 -fold molar excess. Reactions were initiated by mixing $25 \mu \mathrm{l}$ of the reaction buffer containing the substrate, 4-methylumbelliferyl phosphate (Sigma). Final concentrations of calcineurin, calmodulin, and 4-methylumbelliferyl phosphate were $3 \mathrm{nM}, 30 \mathrm{~nm}$, and $250 \mu \mathrm{M}$, 
respectively. After rapid shaking to mix the reactions, the microplates were incubated for 6 hours in a humidified atmosphere at $37^{\circ} \mathrm{C}$. Reactions were stopped by the addition of an alkaline buffer $\left(300 \mathrm{mM} \mathrm{Na}_{2} \mathrm{HPO}_{4}\right.$, $15 \mathrm{~mm}$ EDTA and $15 \mathrm{~mm}$ EGTA, pH 11). Fluorescence was measured as described for the NFAT assay.

\section{Mixed Lymphocyte Reaction}

The two-way mouse mixed lymphocyte reactions using splenocytes isolated from $\mathrm{Balb} / \mathrm{c}$ and $\mathrm{C} 57 \mathrm{BL} / 6$ mice were carried out as previously described. ${ }^{12)}$

\section{$\beta$-Galactosidase Assays}

The ability of compounds to directly inhibit the reporter gene product, $\beta$-galactosidase, was determined as described for the NFAT assay, except that authentic $E$. coli $\beta$-galactosidase (Sigma, Grade VIII, final enzyme concentration was $10^{-5}$ units $/ \mathrm{ml}$ ) was the source of enzyme.

\section{Results \\ Taxonomy}

Analysis of whole-cell hydrolysates of strains $A B$ 2199J-103 and AB 2184C-502 showed that both contained LL-diaminopimelic acid indicating that the cultures have a type I cell wall. ${ }^{13)}$ Neither culture formed sporangia, sclerotia or zoospores. The substrate mycelium of both isolates was branched and did not fragment. The cultural characteristics of both strains are shown in Table 1.

The mature aerial spore mass of strain AB 2199J-103 was gray or grayish brown on most media. The colony reverse was brown. This culture did not produce soluble pigment in ISP-6 or ISP-7 agars. It colored ISP-1 broth a light brown. The pigment appeared not to be melanoid since these are dark. The spores were spherical to oval, had a smooth surface and formed long spiral chains on ISP-2, ISP-3, ISP-4 and ISP-5 media. They typically measured $0.8 \sim 1.1 \mu \mathrm{m} \times 1.0 \sim 1.3 \mu \mathrm{m}$ in diameter. A spore chain of strain AB 2199J-103 is shown in Fig. 1. The

Fig. 1. Scanning electron micrograph of spore chains of strain AB 2199J-103 grown on ISP-4 agar for 10 days at $28^{\circ} \mathrm{C}$.

$$
\text { Bar represents } 1 \mu \mathrm{m} \text {. }
$$

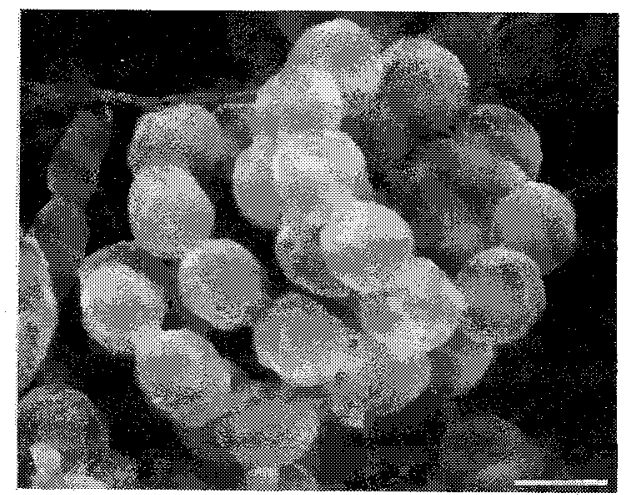

Table 1. Cultural characteristics of strains AB 2199J-103 and 2184C-502.

\begin{tabular}{|c|c|c|c|}
\hline Medium & & AB2199J-103 & AB2184C-502 \\
\hline \multirow{4}{*}{$\begin{array}{l}\text { Yeast extract - malt extract agar } \\
\text { (ISP 2) }\end{array}$} & $\mathrm{G}^{*}:$ & Abundant & Moderate \\
\hline & AM: & $\begin{array}{l}\text { Medium gray }(265)^{* *} \text { to greenish } \\
\text { white }(153)\end{array}$ & Bluish gray $(191)^{* *}$ to pinkish white (9) \\
\hline & R: & Strong brown (55) & Light yellowish brown (76) \\
\hline & SP: & Deep yellowish brown (75) & Light yellowish brown (76) \\
\hline \multirow[t]{4}{*}{ Oatmeal agar (ISP 3) } & G: & Moderate & Moderate \\
\hline & AM: & Grayish brown (61) & Bluish gray (191) \\
\hline & R: & Moderate brown (58) & Light grayish yellowish brown (79) \\
\hline & SP: & Absent & Absent \\
\hline \multirow[t]{4}{*}{ Inorganic salts - starch agar (ISP 4) } & G: & Abundant & Abundant \\
\hline & AM: & Light brownish gray (63) & Bluish gray (191) \\
\hline & R: & Moderate yellowish brown (77) & Light yellowish brown (76) \\
\hline & SP: & Light yellowish brown (76) & Absent \\
\hline \multirow[t]{4}{*}{ Glycerol-asparagine agar (ISP 5) } & G: & Poor & Poor \\
\hline & AM: & Grayish brown (61) & Light bluish gray (190); no spores \\
\hline & R: & Moderate brown (58) & Yellowish white (92) \\
\hline & SP: & Absent & Absent \\
\hline \multirow{4}{*}{$\begin{array}{l}\text { Peptone - yeast extract iron agar } \\
\text { (ISP 6) }\end{array}$} & G: & Moderate & Moderate \\
\hline & AM: & Pinkish white (9) & $\begin{array}{l}\text { Absent; substrate mycelium is grayish } \\
\text { reddish orange (39) }\end{array}$ \\
\hline & R: & Moderate orange yellow (71) & Light yellowish brown (76) \\
\hline & SP: & Absent & Absent \\
\hline \multirow[t]{4}{*}{ Tyrosine agar (ISP 7) } & $\mathrm{G}:$ & Moderate & Poor \\
\hline & AM: & Light grayish brown (60) & Bluish white (189) \\
\hline & R: & Grayish yellowish brown (80) & Pale orange yellow (73) \\
\hline & SP: & Absent & Absent \\
\hline
\end{tabular}

* Abbreviations: $\mathrm{G}=$ growth, $\mathrm{AM}=$ aerial mycelium, $\mathrm{R}=$ reverse, $\mathrm{SP}=$ soluble pigment.

** Color and number in parenthesis follow the color standard in KeLLY, K. L. \& D. B. JUDD: ISCC-NBS Color-Name Charts Illustrated with Centroid Colors. U.S. Dept. of Comm. Suppl. to Cir. 553, Washington, D.C. (1976). 
bluish gray on ISP-2, ISP-3 and ISP-4 media. No spores were observed on ISP-5 agar. The colony reverse was light yellowish brown on most media. This culture did not produce melanoid pigment in ISP-6, ISP-7 or ISP-1 media. Long spiral spore chains were formed on ISP-2, ISP-3 and ISP-4 agars. The spores had a hairy surface, were spherical and measured $1.0 \mu \mathrm{m}$ in diameter. A typical spore chain of strain AB $2184 \mathrm{C}-502$ is shown in Fig. 2.

The whole-cell analyses and morphological characteristics of these two cultures indicate that they both belong to the genus Streptomyces. They have been designated Streptomyces sp. AB 2199J-103 and Streptomyces sp. AB 2184C-502.

\section{Isolation and Structure Determination}

Upon completion of fermentation of strain $\mathrm{AB}$ 2199J-103, the Amberlite XAD-16 resin and mycelial mass were removed by centrifugation and filtration before the solids were eluted with 14 liters of methanol. The methanol extract was concentrated to yield $72 \mathrm{~g}$ of crude material which was triturated sequentially with one liter each of; hexane, EtOAc, $\mathrm{Me}_{2} \mathrm{CO}, \mathrm{MeOH}$ and $\mathrm{H}_{2} \mathrm{O}$. The $\mathrm{MeOH}$ triturate was found to inhibit NFAT dependent transcription and was concentrated to yield $35 \mathrm{~g}$ of an oil which was subjected to column chromatography on an XAD-16 resin column developed in an aqueous methanol gradient. NFAT inhibitory fractions which eluted with $25 \% \mathrm{MeOH}$ were combined and concentrated to yield $2.8 \mathrm{~g}$ of oil which was partitioned between EtOAc-EtOH - $\mathrm{H}_{2} \mathrm{O}(2: 1: 2)$. The upper layer from this partition was concentrated to yield $1.6 \mathrm{~g}$ of an oil which was subjected to column chromatography on Sephadex LH-20 developed in $\mathrm{MeOH}$ to yield $117 \mathrm{mg}$ of pure NFAT-68.

A fast atom bombardment positive ion mass spectrum

Fig. 2. Scanning electron micrograph of spore chains of strain AB 2184C-502 grown on ISP-4 agar for 10 days at $28^{\circ} \mathrm{C}$

Bar represents $1 \mu \mathrm{m}$.

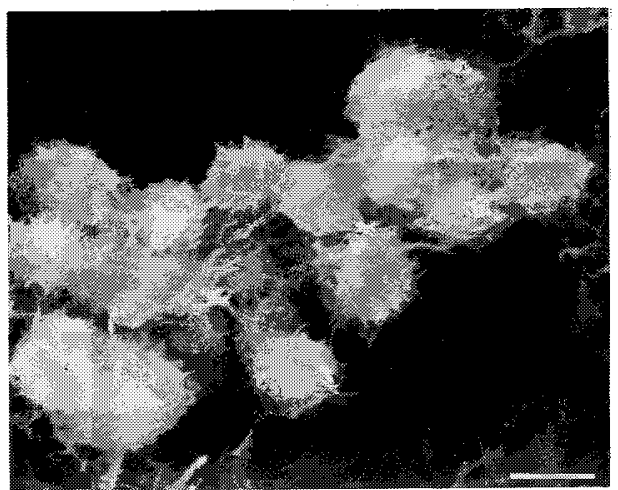

of NFAT-68 gave an $\mathrm{M}+\mathrm{H}$ ion at 350 , indicating a molecular weight of 349 . A ${ }^{13} \mathrm{C}$ NMR spectrum contained 18 carbon signals with 19 attached protons. A ${ }^{14} \mathrm{~N}$ NMR spectrum contained one $\mathrm{N}$ signal at $\delta$ $135.77 \mathrm{ppm}$ (relative to formamide) indicative of an $\mathrm{N}$-acetate. Analysis of data from COSY, HMBC and HMQC experiments suggested the presence of a 1,2,3,5substituted aromatic ring (see Table 2, C-8 C-13) and a branched chain ester moiety $(\mathrm{C}-1 \sim \mathrm{C}-7$ and C-14 C-15). Attachment of the branched chain ester and functional groups to the aromatic moiety was determined by analysis of $\mathrm{NOE}^{14}$ experiments in $\mathrm{CD}_{3} \mathrm{OD}$ and $d_{6}$-DMSO and by considerations of chemical shifts for the aromatic ring carbons as shown in 1.

Upon completion of fermentation of strain $\mathrm{AB}$ $2184 \mathrm{C}-502$, the XAD-4 resin and mycelial mass were removed by centrifugation and filtration before the solids were eluted with 12 liters of $\mathrm{MeOH}$. The $\mathrm{MeOH}$ eluate was concentrated to yield $55 \mathrm{~g}$ of material which was then triturated sequentially with one liter volumes each of; hexane, EtOAc, $\mathrm{Me}_{2} \mathrm{CO}, \mathrm{MeOH}$ and $\mathrm{H}_{2} \mathrm{O}$. Activity was observed in the aqueous triturate which was concentrated to yield $46 \mathrm{~g}$ of solid material which was subjected to chromatography on a column of SP-207 eluted with an aqueous methanol gradient. Active fractions from this column were combined and concentrated to yield $5.7 \mathrm{~g}$ of material which was then subjected to flash reversed phase C-18 chromatography developed with an aqueous methanol step gradient. Active material eluted with $25 \%$ methanol was concentrated to yield $320 \mathrm{mg}$ of material which was subjected to flash reversed phase chromatography on bonded-phase amino packing eluted with an

Table 2. NMR assignments for NFAT-68 (in $\mathrm{CD}_{3} \mathrm{OD}$ )

\begin{tabular}{ccc}
\hline $\begin{array}{c}\text { Carbon } \\
\text { number }\end{array}$ & $\begin{array}{c}{ }^{13} \mathrm{C} \text { NMR shift } \\
\text { (mult) }\end{array}$ & Attached ${ }^{1} \mathrm{H}$ NMR shift \\
\hline 1 & $169.7(\mathrm{Q})$ & \\
$1-\mathrm{OCH}_{3}$ & $51.9\left(\mathrm{CH}_{3}\right)$ & $3.70(\mathrm{~s}, 3 \mathrm{H})$ \\
2 & $146.2(\mathrm{CH})$ & $5.72(\mathrm{~d}, 1 \mathrm{H}, J=15.7 \mathrm{~Hz})$ \\
3 & $151.4(\mathrm{CH})$ & $7.22(\mathrm{brd}, 1 \mathrm{H}, J=15.7 \mathrm{~Hz})$ \\
4 & $133.7(\mathrm{Q})$ & \\
5 & $116.1(\mathrm{CH})$ & $5.84(\mathrm{br} \mathrm{d}, 1 \mathrm{H}, J=9.9 \mathrm{~Hz})$ \\
6 & $40.8(\mathrm{CH})$ & $3.01(\mathrm{mult}, 1 \mathrm{H})$ \\
7 & $75.1(\mathrm{CH})$ & $4.80(\mathrm{~d}, 1 \mathrm{H}, J=7.2 \mathrm{~Hz})$ \\
8 & $133.2(\mathrm{Q})$ & \\
9 & $140.3(\mathrm{Q})$ & \\
10 & $127.8(\mathrm{Q})$ & \\
$10-\mathrm{NAc}$ & $172.5(\mathrm{Q})$ & \\
& $23.3(\mathrm{CH})$ & $2.15(\mathrm{~s}, 3 \mathrm{H})$ \\
11 & $109.3(\mathrm{CH})$ & $6.80(\mathrm{~d}, 1 \mathrm{H}, J=2.9 \mathrm{~Hz})$ \\
12 & $150.9(\mathrm{Q})$ & \\
13 & $112.5(\mathrm{CH})$ & $6.57(\mathrm{~d}, 1 \mathrm{H}, J=2.9 \mathrm{~Hz})$ \\
14 & $15.9(\mathrm{CH})$ & $1.63(\mathrm{br} \mathrm{s}, 3 \mathrm{H})$ \\
15 & $12.4(\mathrm{CH})$ & $1.02(\mathrm{~d}, 3 \mathrm{H}, J=6.6 \mathrm{~Hz})$
\end{tabular}


Fig. 3. Structures of NFAT-68 and NFAT- 133 .<smiles>COC(=O)/C=C/C(C)=C/C(C)C(O)c1cc(O)cc(NC(C)=O)c1O</smiles>

(1) NFAT-68

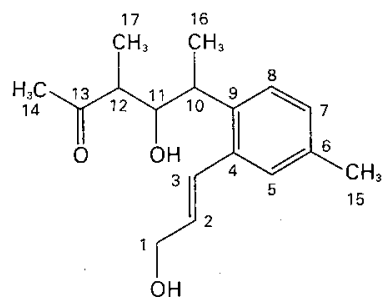

(2) NFAT-133 aqueous acetonitrile step gradient. Active material from this column eluted with $30 \%$ acetonitrile, was concentrated to yield $59 \mathrm{mg}$ of material and was subjected to chromatography on Sephadex LH-20 developed with EtOH $-\mathrm{H}_{2} \mathrm{O}(1: 1)$. Active fractions from this column were combined to yield $2.1 \mathrm{mg}$ of pure NFAT- 133 .

An ammonium ion DCI mass spectrum of NFAT-133 gave a highest mass peak of $m / z 294\left[\mathrm{M}+\mathrm{NH}_{4}\right]^{+}$and a fast atom bombardment positive ion mass spectrum gave a highest mass peak at $m / z 299[\mathrm{M}+\mathrm{Na}]^{+}$ suggesting a molecular weight of $276 . \mathrm{A}^{13} \mathrm{C}$ NMR spectra indicated 17 unique carbon atoms with 22 attached protons consistent with a molecular formula of $\mathrm{C}_{17} \mathrm{H}_{24} \mathrm{O}_{3}$, containing 2 exchangeable protons. ${ }^{13} \mathrm{C}$ and ${ }^{1} \mathrm{H}$ NMR spectra (see Table 3) suggested the presence of a 1,2,4-trisubstituted benzene moiety with coupled proton signals at $\delta 7.24(\mathrm{C}-5), 7.07(\mathrm{C}-7)$ and $7.17(\mathrm{C}-8)$. $\mathrm{HMBC}^{15)}$ and $\mathrm{HMQC}^{16)}$ experiments defined the moieties attached to this aromatic ring as shown in $\mathbf{2}$.

Strain AB 2184C-502 also yielded the previously reported compound conglobatin ${ }^{17)}$ which had an $\mathrm{IC}_{50}$ of $0.63 \mu \mathrm{g} / \mathrm{ml}$ in the NFAT-dependent transcription assay.

\section{Immunosuppressant Activity}

Exposure to phorbol ester (P), as an activator of protein kinase $\mathrm{C}$, and ionomycin (I), as a $\mathrm{Ca}^{2+}$ ionophore, stimulates NFAT-dependent transcription (Fig. 4A). ${ }^{5}$ Both agents are required for expression of $\beta$-galactosidase since production in the presence, of either activator alone is not significantly different from background levels. As shown in Fig. 4B, expression of $\beta$-galactosidase can be detected after 3 hours of stimulation (closed bars) and a strong response (10-fold background levels, hatched bars) was detected after 6 hours. Under these conditions, cyclosporin A and the FK506 analog, ascomycin inhibited NFAT-dependent transcription of the $\beta$-galactosidase reporter gene with $\mathrm{IC}_{50}$ values of 0.6 and $0.1 \mathrm{ng} / \mathrm{ml}$,
Table 3. NMR assignments for NFAT-133 (in $\mathrm{CD}_{3} \mathrm{OD}$ ).

\begin{tabular}{ccl}
\hline $\begin{array}{c}\text { Carbon } \\
\text { number }\end{array}$ & $\begin{array}{c}{ }^{13} \mathrm{C} \text { NMR shift } \\
\text { (mult) }\end{array}$ & Attached ${ }^{1}$ H NMR shift \\
\hline 1 & $63.7\left(\mathrm{CH}_{2}\right)$ & $4.24(\mathrm{dd}, 1 \mathrm{H}, J=5.5,1.8 \mathrm{~Hz})$ \\
2 & $132.8(\mathrm{CH})$ & $6.16(\mathrm{dt}, 1 \mathrm{H}, J=15.6,5.5 \mathrm{~Hz})$ \\
3 & $129.3(\mathrm{CH})$ & $6.92(\mathrm{dt}, 1 \mathrm{H}, J=15.6,1.8 \mathrm{~Hz})$ \\
4 & $137.2(\mathrm{CH})$ & \\
5 & $128.6(\mathrm{Q})$ & $7.24(\mathrm{~d}, 1 \mathrm{H}, J=1.8 \mathrm{~Hz})$ \\
6 & $137.0(\mathrm{Q})$ & \\
7 & $129.7(\mathrm{CH})$ & $7.07(\mathrm{dd}, 1 \mathrm{H}, J=7.8,1.8 \mathrm{~Hz})$ \\
8 & $128.0(\mathrm{CH})$ & $7.17(\mathrm{~d}, 1 \mathrm{H}, J=7.8 \mathrm{~Hz})$ \\
9 & $140.2(\mathrm{Q})$ & \\
10 & $39.8(\mathrm{CH})$ & $3.08(\mathrm{dq}, 1 \mathrm{H}, J=9.0,6.8 \mathrm{~Hz})$ \\
11 & $76.6(\mathrm{CH})$ & $4.20(\mathrm{dd}, 1 \mathrm{H}, J=9.0,3.7 \mathrm{~Hz})$ \\
12 & $51.2(\mathrm{CH})$ & $2.34(\mathrm{qd}, 1 \mathrm{H}, J=7.0,3.7 \mathrm{~Hz})$ \\
13 & $214.2(\mathrm{Q})$ & \\
14 & $28.4\left(\mathrm{CH}_{3}\right)$ & $2.05(\mathrm{~s}, 3 \mathrm{H})$ \\
15 & $21.0\left(\mathrm{CH}_{3}\right)$ & $2.25(\mathrm{~s}, 3 \mathrm{H})$ \\
16 & $19.2\left(\mathrm{CH}_{3}\right)$ & $1.26(\mathrm{~d}, 3 \mathrm{H}, J=6.8 \mathrm{~Hz})$ \\
17 & $9.7\left(\mathrm{CH}_{3}\right)$ & $0.92(\mathrm{~d}, 3 \mathrm{H}, J=7.0 \mathrm{~Hz})$ \\
\hline
\end{tabular}

respectively. Cytotoxicity, as measured by MTT reduction or ability to exclude vital stains was not observed until cells were exposed to $1 \mu \mathrm{g} / \mathrm{ml}$ concentrations of either agent. Using this assay to screen for immunosuppressants resulted in the identification of two Streptomyces sp. fermentation extracts that inhibited NFAT-dependent transcription. Subsequent bioassay guided isolations resulted in the identification of NFAT-68 and NFAT-133. Each compound inhibited NFAT-dependent transcription with $\mathrm{IC}_{50}$ concentrations slightly less than $1 \mu \mathrm{g} / \mathrm{ml}$ (Table 4). These compounds were apparently selective inhibitors of NFAT-dependent transcription since marked cytotoxicity was not observed unless cells were exposed to concentrations 7 to 60 -fold higher. The compounds also inhibited antigen-dependent activation of $\mathrm{T}$ cells in a two way mixed lymphocyte reaction. Neither NFAT-68 or NFAT-133 inhibited $\beta$-galactosidase directly or inhibited the phosphatase activity of calcineurin (Table 4). 
Fig. 4. NFAT-dependent expression of $\beta$-galactosidase
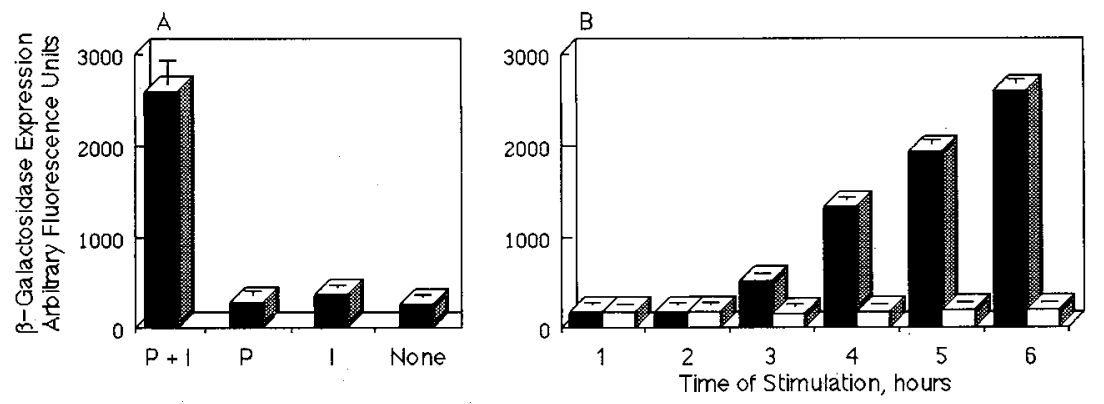

Table 4. Biological activity of NFAT-68 and NFAT- 133.

\begin{tabular}{ccccccc}
\hline Sample & $\begin{array}{c}\text { NFAT } \\
\text { assay }\end{array}$ & $\begin{array}{c}\text { Jurkat } \\
\text { toxicity }\end{array}$ & $\begin{array}{c}\text { MLR } \\
\text { assay }\end{array}$ & $\begin{array}{c}\text { Lymphocyte } \\
\text { toxicity }\end{array}$ & $\begin{array}{c}\text { Calcineurin } \\
\text { phosphatase }\end{array}$ & $\begin{array}{c}\beta \text {-Galactosidase } \\
\text { activity }\end{array}$ \\
\hline NFAT-68 & $0.22 \pm 0.06$ & $14 \pm 2$ & $0.65 \pm 0.21$ & $4 \pm 1$ & $>50$ & $>50$ \\
NFAT-133 & $0.70 \pm 0.05$ & $5 \pm 1$ & $0.3 \pm 0.1$ & $12 \pm 5$ & $>50$ & $>50$ \\
\hline
\end{tabular}

$\mathrm{IC}_{50}$ in assay, $\mu \mathrm{g} / \mathrm{ml}$.

\section{Discussion}

The mixed lymphocyte reaction is considered the in vitro correlate of graft rejection and has been widely used to screen for immunosuppressants. Assessing effects of agents on the antigen-dependent mitogenic response of splenocytes is the least mechanistically restrictive screen for immunosuppressants and was used to discover FK506. ${ }^{18)}$ Despite these obvious advantages, the mixed lymphocyte reaction is a time-consuming laborious assay that requires the use of animals. In contrast, the NFAT-lac $Z \quad \beta$-galactosidase reporter gene construct assay is relatively rapid and only requires cell culture facilities. However, compounds active in this assay would be expected to act on early $\mathrm{Ca}^{2+}$-dependent steps of $\mathrm{T}$ cell activation in a manner similar to that of cyclosporin A or FK506.

Simple aromatic compounds from the fermentation broths of Streptomyces sp. were discovered with the NFAT-lacZ $\beta$-galactosidase reporter gene construct assay. These compounds inhibited NFAT-dependent transcription at concentrations that were not apparently toxic to the cells. As expected from the design of the screen, the compounds inhibited the mixed lymphocyte reaction with similar potency. These compounds may provide insight into signalling pathways of early $T$ cell activation.

\section{Acknowledgments}

The authors are grateful to Dr. MaHLon Miller and Ms. FIGEN SEILER for scanning electron microscopy and the late Mr. PReston Hill for spectral measurements.

\section{References}

1) Crabtree, G. R. \& N. A. Clipstone: Signal transmission between the plasma membrane and nucleus of $\mathrm{T}$ lymphocytes. Annu. Rev. Biochem. 63: $1045 \sim 1083,1994$

2) Handschumacher, R. E.; M. W. Harding, J. Rice, R. J. Drugge \& D. W. Speicher: Cyclophilin: A specific cytosolic binding protein for cyclosporin A. Science 226: $544 \sim 547,1984$

3) Harding, M. W.; A. Galat, D. E. Uehling \& S. L. SCHREIBER: A receptor for the immunosuppressant FK 506 is a cis-trans peptidyl-prolyl isomerase. Nature 341: $758 \sim 760,1989$

4) Bierer, B. E.; P. K. Somers, T. J. Wandless, S. J. Burakoff \& S. L. SChreiber: Probing immunosuppressant action with a nonnatural immunophilin ligand. Science 250: 556 559, 1990

5) Mattila, P. S.; K. S. Ullman, S. Fiering, E. A. Emmel, M. MCCutcheon, G. R. Crabtree \& L. A. Herzenberg: The actions of cyclosporin A and FK506 suggest a novel step in the activation of $\mathrm{T}$ lymphocytes. EMBO J. 9: 4425 4433, 1990

6) LiU, J.; J. J. Farmer, W. S. Lane, J. Friedman, I. WeISSMAN \& S. L. SchreIber: Calcineurin is a common target of cyclophilin-cyclosporin A and FKBP-FK506 complexes. Cell 66: 807 815, 1991

7) Hayakawa, M.; T. Kajiura \& H. Nonomura: New methods for the highly selective isolation of Streptosporangium and Dactylosporangium from soil. J. Ferm. Biotech. 72: 327 333, 1991

8) Hussein, A. M.; A. M. Allam \& A. M. RagaB: Taxonomical studies on thermophilic actinomycetes of some soils of Egypt. Ann. Microbiol. 25: 19 28, 1975

9) Shirling, E. B. \& D. Gottlieb: Methods for characterization of Streptomyces species. Int. J. Syst. Bacteriol. 16: $313 \sim 340,1966$

10) Hasekawa, T; M. Takizawa \& S. Tanida: A rapid analysis for chemical grouping of aerobic actinomycetes. J. Gen. Appl. Microbiol. 29: 319 322, 1983

11) U.S. Department of Commerce. National Bureau of Standards: ISCC-NBS Centroid Color Charts. NBS Special Publication 440, 1976 
12) MCAlpine, J. B.; J. P. KaRwowski, M. JACKSON, M. M. Mullally, J. E. Hochlowski, U. Premachandran \& N. S. Burres: MLR-52, (4'-demethylamino-4',5'-dihydroxystaurosporine), a new inhibitor of protein kinase $\mathrm{C}$ with immunosuppressive activity. J. Antibiotics 47: $281 \sim 288,1994$

13) Lechevalier, M. P. \& H. A. Lechevalier: Chemical composition as a criterion in the classification of aerobic actinomycetes. Int. J. Syst. Bacteriol. 20: 435 443, 1970

14) Bothner-By, A. A.; R. L. Stephens, J. M. Lee, C. D. WARREN \& R. W. JEANLOZ: Structure determination of a tetrasaccharide: Transient nuclear Overhauser effects in the rotating frame. J. Am. Chem. Soc. 106: $811 \sim 813$, 1984

15) Muller, L.: Sensitivity enhanced detection of weak nuclei using heteronuclear multiple quantum coherence. J. Am.
Chem. Soc. 101: 4481 4484, 1979

16) BAX, A. \& M. F. Summers: ${ }^{1} \mathrm{H}$ and ${ }^{13} \mathrm{C}$ assignments from sensitivity-enhanced detection of heteronuclear multiplebond connectivity by $2 \mathrm{D}$ multiple quantum NMR. J. Am. Chem. Soc. 108: 2093 2094, 1986

17) Westley, J.; C. Liu, R. Evans \& J. Blount: Conglobatin, a novel macrolide dilactone from Streptomyces conglobatus ATCC 31005. J. Antibiotics 32: 874 877, 1979

18) Kino, T.; H. Hatanaka, M. Hashimoto, M. Nishiyama, T. Goto, M. Okuhara, M. Kohsaka, H. Aoki \& H. IMANAKA: FK-506, a novel immunosuppressant isolated from a Streptomyces. I. Fermentation, isolation, and physico-chemical and biological characteristics. J. Antibiotics 40: 1249 1255, 1987 